\title{
Limnological characteristics of a hydrographic basin of the Brazilian semiarid region
}

Características limnológicas de uma bacia hidrográfica da região semiárida brasileira

\section{Rodrigo Sávio Teixeira de Moura ${ }^{1}$ and Gustavo Gonzaga Henry-Silva ${ }^{1}$}

${ }^{1}$ Laboratório de Limnologia e Qualidade de Água, Departamento de Ciências Animais, Universidade Federal Rural do Semiárido - UFERSA, Av. Francisco Mota, 572, CEP 59625-300, Mossoró, RN, Brazil e-mail: savio.ww@gmail.com; gustavo@ufersa.edu.br

\begin{abstract}
Aim: This study aimed to verify if the water characteristics of Apodi/Mossoró River basin aquatic environments are mainly determined by a longitudinal gradient or its rain regime. Methods: Through one year quarterly sample expeditions were carried (August/2007 to May/2008), in 24 sampling stations. In each place, water samples were collected and direct parameters were measured. Concentrations of nutrients, biochemical oxygen demand and thermotolerant coliforms were determined. For ordination of the sampling stations and in order to find patterns in water quality was conducted a Principal Components Analysis. Results: The results showed that points inside urban agglomerates had depreciated water quality, with high concentrations of nutrients. In general, it was not possible to define a longitudinal gradient for the studied variables, probably due to anthropogenic interferences along the basin. Otherwise, the effect of rainy and dry seasons were marked, resulting in a grouping of the sampling stations during the dry months, mainly due to the raised values of nutrients and biochemical oxygen demand. Conclusion: It could be concluded that in the rainy period a homogenizer effect occurred, not being verified the zonation of the hydrographic basin aquatic environments. The anthropogenic pressures probably contributed for the absence of a longitudinal gradient, since they generate disorders which modify the aquatic environments.
\end{abstract}

Keywords: ecological concepts; environmental monitoring; river continuum; limnology.

Resumo: Objetivo: Este estudo teve como objetivo verificar se as características da água dos ambientes aquáticos da bacia hidrográfica do Rio Apodi/Mossoró são determinadas principalmente por um gradiente longitudinal ou por seu regime de chuvas. Métodos: A cada três meses foram realizadas coletas, durante o período de um ano (Agosto/20007 a Maio/2008), em 24 estaçôes de amostragem. Em cada estação amostras de água foram coletadas e parâmetros diretos foram mensurados. Em laboratório as concentraçóes de nutrientes, demanda bioquímica de oxigênio e coliformes termotolerantes foram determinadas. Para ordenaçáo dos pontos de amostragem e no intuito de encontrar padrôes na qualidade de água foi aplicada uma Análise dos Componentes Principais. Resultados: Os resultados mostraram que as estaçóes localizadas em aglomerados urbanos apresentaram altas concentraçóes de nutrientes. Em geral não foi possível definir um gradiente longitudinal para as variáveis consideradas, provavelmente devido às interferências antropogênicas ao longo da bacia. A sazonalidade foi marcante, resultando em um agrupamento das estaçóes de amostragem durante o período seco, principalmente devido aos valores elevados de nutrientes e demanda bioquímica de oxigênio. Conclusão: Pode-se concluir que no período chuvoso ocorreu um efeito homogeneizador, não sendo verificada uma zonação dos ambientes aquáticos da bacia hidrográfica. As pressóes antropogênicas também contribuíram para a ausência de um gradiente longitudinal, uma vez que estes distúrbios geram desordem que modificam as características dos ambientes aquáticos.

Palavras-chave: conceitos ecológicos; monitoramento ambiental; contínuo fluvial; limnologia. 


\section{Introduction}

The hydrographic basin is being used as a very embracing model to understand the functioning of aquatic ecosystems. These environments are part of larger systems, involving aspects of geology, vegetation, climate and land use and occupation, consisting of a mosaic of functional subsystems interconnected by biotic and abiotic processes (Smith \& Petrere Junior, 2001; Schiavetti \& Camargo, 2002; Wu et al., 2012). Currently some paradigms have directed studies and watershed management, incorporating several ecological concepts, such as the River Continnum Concept (Vannote et al., 1980); the Serial Discontinuity Concept (Ward \& Stanford, 1983), Flood Pulse Concept; Theory of the Nutrient Spirraling Concept (Elwood et al., 1983) and the concepts related to the Landscape Ecology (Hansson et al., 1995).

The River Continuum Concept (RCC) mentions that lotic environments have gradients (headwater toward the estuary) of their physical, chemical and biological characteristics that are modifying themselves in space in a continuous and predictable way. This concept, however, focuses on the original stream ecosystems that are not subject to human interferences, such as sewage discharge and construction of reservoirs (Johnson et al., 1995; Statzner \& Higler, 1985). The Serial Discontinuity Concept highlights dams as agents that disrupts a possible gradient of the river in relation to environmental conditions, producing longitudinal changes, as much downstream as to the upstream, in the biotics and abiotics processes (Ward \& Stanford, 1983). Lately, the concepts of the landscape ecology had been incorporated to the understanding of the functioning of the lotic ecosystems (Thorp et al., 2006).

In the semiarid watersheds of Rio Grande do Norte the construction of reservoirs and the urban effluents discharges without treatment represent the main human interferences to aquatic ecosystems. In these watersheds are observed: (i) relatively well preserved areas, especially next to its headers; (II) sections with dams; (III) areas next to the estuary, impacted by shrimp farming and salt activities; and (III) highly impacted areas by domestic sewers, next to the urban centers. Importantly, the Apodi/ Mossoró river basin will receive water from the São Francisco river transposition, resulting in physical and chemical changes of water, and the mixture of aquatic biological communities.

This study was based on the hypothesis that the water characteristics of a semiarid hydrographic basin are more explained by flood based ecological concepts rather than spatial gradient models. In this context, the objective was to verify if the water characteristics of Apodi/Mossoró river basin aquatic environments are more determined by a longitudinal gradient or its rain regime.

\section{Material and Methods}

The area for this study was the the Apodi/ Mossoró river hydrographic basin, Rio Grande do Norte State, Brazil. The basin covers 52 cities with a total extension of $210 \mathrm{~km}$, with an approximated area of $14.276 \mathrm{~km}^{2}$. It is located between the latitudes $06^{\circ} 22^{\prime} 18^{\prime \prime} \mathrm{S}$ and $04^{\circ} 57,20^{\prime \prime} \mathrm{S}$ and the longitudes $038^{\circ} 27,22^{\prime \prime} \mathrm{W}$ and $037^{\circ} 08>11^{\prime \prime} \mathrm{W}$ (Figure 1). The region has climate conditions of semidryness - predominantly flat ground and with low capacity of available water storage. In almost the entire length of the Apodi/Mossoró basin predominates the BSw'h' climate type according to the Köppen classification.

The study was carried during one year, in four collections of quarterly frequency; two collections in the dry season (August and November 2007) and two collections in the rainy season (February and May 2008). In total, 24 sampling stations were selected, distributed from the headers to the estuary region of the hydrographic basin, including from stations on the main river course to reservoirs and smaller impoundments on the river main channel. In the upper part of the basin six points had been sampled (from 1 to 6 ); in the medium course five points (from 7 to 11); in the low course 10 points (from 12 to 21 ) and in the estuary region 3 points (from 22 to 24). The stretches corresponding to the points from 13 to 20 cross the urban area of the city of Mossoró and the point 5 crosses the urban zone of the city of Pau dos Ferros. The sampling stations had been georeferenced with a portable GPS device (Global Positioning System).

In each sampling station, using a multi-parameter sensor, the direct parameters were measured: $\mathrm{pH}$, Dissolved Oxygen, Electric Condutivity and Total Dissolved Solids. Were made in the laboratory analysis of inorganic phosphate (Golterman et al., 1978); N-Nitrate (Mackereth et al., 1978); N-Nitrite (Mackereth et al., 1978); N-Ammonium (Koroleff, 1976); Biochemical Oxygen Demand (BOD), and Thermotolerant Coliforms. The rainfall data were obtained from meteorological stations monitored by the Agência Nacional de Água (ANA), distributed throughout the hydrographic basin of the Apodi/ Mossoró river. The Principal Components Analysis 


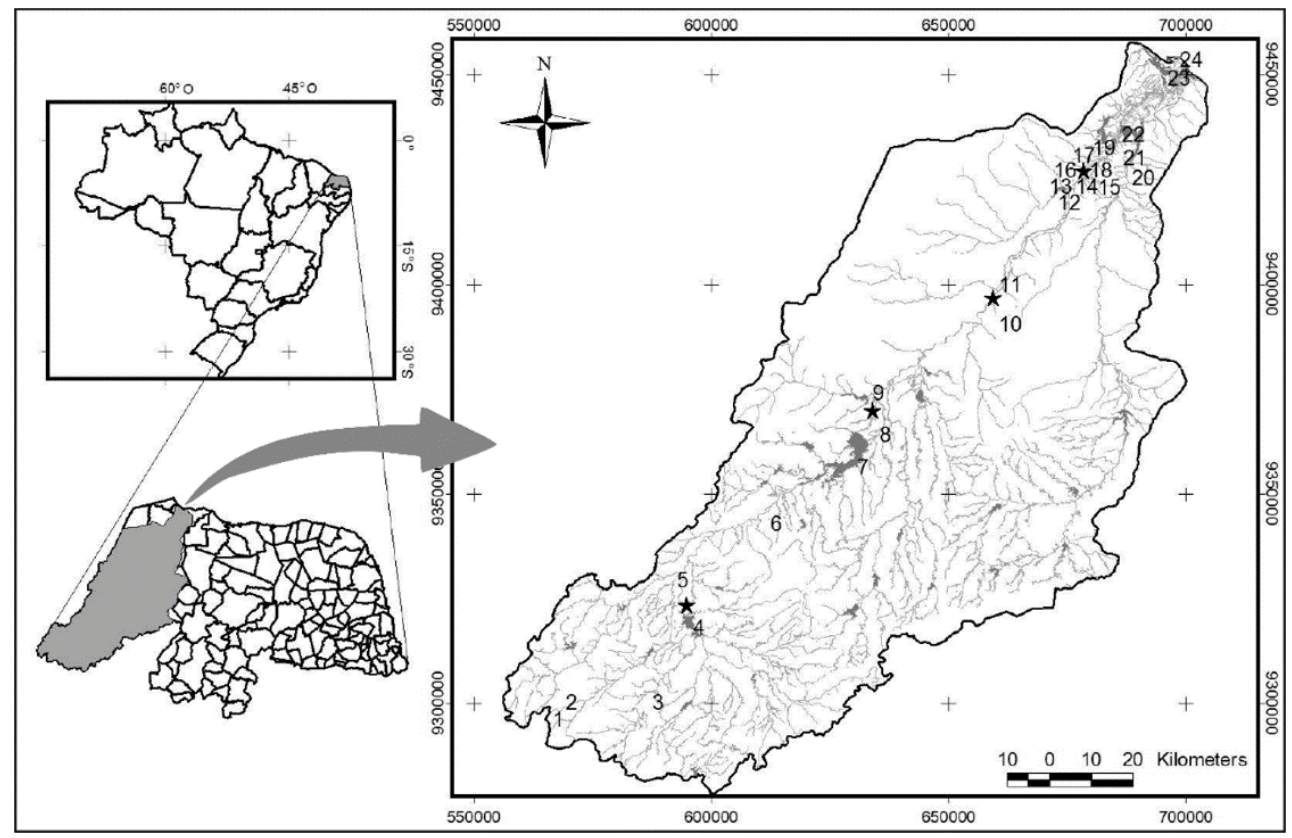

Figure 1. Localization of the sampling points in the Apodi/Mossoró river hydrographic basin, semiarid of Rio Grande do Norte, Brazil, with highlights of water bodies (reservoirs and impoundments). Black stars mark the major cities.

(PCA) was applied (Bouroche \& Saporta, 1982), from the matrix of correlation of the physical and chemical variables, with the intention of ordering the sampling points. Correlation analysis were made in order to identify possible relationships between parameters. The statistical analysis was run on the STATISTICA v7.0 software (STATSOFT, Inc.).

\section{Results and Discussion}

In 2007 there was an accumulated precipitation of $759.8 \mathrm{~mm}$, with precipitations from zero to one millimeter between the months of August and November. Already for 2008, the annual accumulated was $1005.3 \mathrm{~mm}$, with March being the month of greatest precipitation $(385.2 \mathrm{~mm})$ (Figure 2). In this period, the majority of the reservoirs of the hydrographic basin "overflowed", and also the reservoir of Santa Cruz, that has the cumulative capacity of 600 million cubic meters of water, causing floods in the medium and low courses of the Apodi/Mossoró river hydrographic basin.

The Principal Components Analyses had reveled similar groupings for the sampling points in dry periods (August and November of 2007) and before the beginning of the rainy season (February/2008). However, this pattern modified itself during the period of most intense rains (May/2008). The PCA for the month of August 2007, November 2007 and February 2008 (dry period) summarized 59.26,

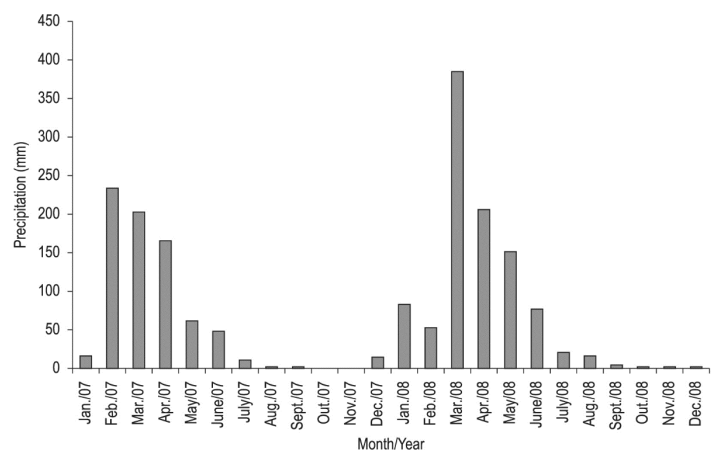

Figure 2. Pluviometric precipitations of the years of 2007 and 2008, in the Apodi/Mossoró river hydrographic basin.

58.5 and $58.25 \%$ of the total variability (Figures 3, 4 and 5). For the rainy period (May 2008) the PCA explained $43.57 \%$ of total data variance (Figure 6).

The sampling points located in the urban zones of Pau dos Ferros (high course) and Mossoró (low course) cities, to note, sampling points 5 and from 14 to 17 , had presented the biggest values of phosphate, $\mathrm{N}$-ammonium, $\mathrm{N}$-nitrite, $\mathrm{N}$-nitrate and thermotolerant coliforms (Figure 7 ). In these points the BOD levels had varied from 8.2 to $37.9 \mathrm{mg} \mathrm{L}^{-1}$, indicating an intense microbiological activity in the decomposition of the available organic matter. It should be noted that the decomposition of organic substance and reduction of nitrogen requires intense consumption of oxygen, which would explain the 
(a)

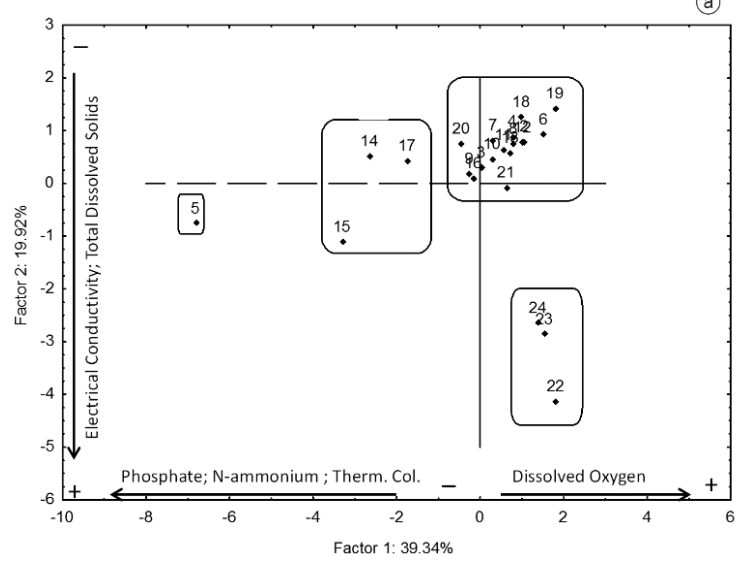

(b)

\begin{tabular}{ccc}
\hline Variables & Factor 1 & Factor 2 \\
\hline EC $\left(\mathrm{mS} \mathrm{cm}^{-1}\right)$ & 0.32 & $\mathbf{- 0 . 9 2}$ \\
TDS $\left(\mathrm{mg} \mathrm{L}^{-1}\right)$ & 0.32 & $\mathbf{- 0 . 9 2}$ \\
pH & 0.55 & 0.18 \\
Phosphate $\left(\mathrm{mg} \mathrm{L}^{-1}\right)$ & $\mathbf{- 0 . 9 3}$ & -0.10 \\
N-Nitrate $\left(\mathrm{mg} \mathrm{L}^{-1}\right)$ & -0.47 & -0.37 \\
N-Nitrite $\left(\mathrm{mg} \mathrm{L} \mathrm{L}^{-1}\right)$ & -0.38 & 0.15 \\
N-Amm. $\left(\mathrm{mg} \mathrm{L}^{-1}\right)$ & $\mathbf{- 0 . 9 2}$ & -0.09 \\
DO $\left(\mathrm{mg} \mathrm{L}^{-1}\right)$ & $\mathbf{0 . 6 1}$ & 0.28 \\
BOD $\left(\mathrm{mg} \mathrm{L}^{-1}\right)$ & -0.56 & 0.00 \\
Ther.Col. (NMP) & $\mathbf{- 0 . 8 1}$ & -0.01 \\
\hline \% Explication & 39.34 & 19.92 \\
\hline
\end{tabular}

Figure 3. Principal Components Analysis of the sampling points of the Apodi/Mossoró river hydrographic basin, in the month of August of 2007. a) Representation of the two first PCA components; b) Variables correlation values. EC: Electric Conductivity; TDS: Total dissolved solids; N-Amm.: Ammoniacal nitrogen; DO: Dissolved oxygen; BOD: Biochemical Oxygen Demand; Ther.Col.: Thermotolerant Coliforms.

(a)

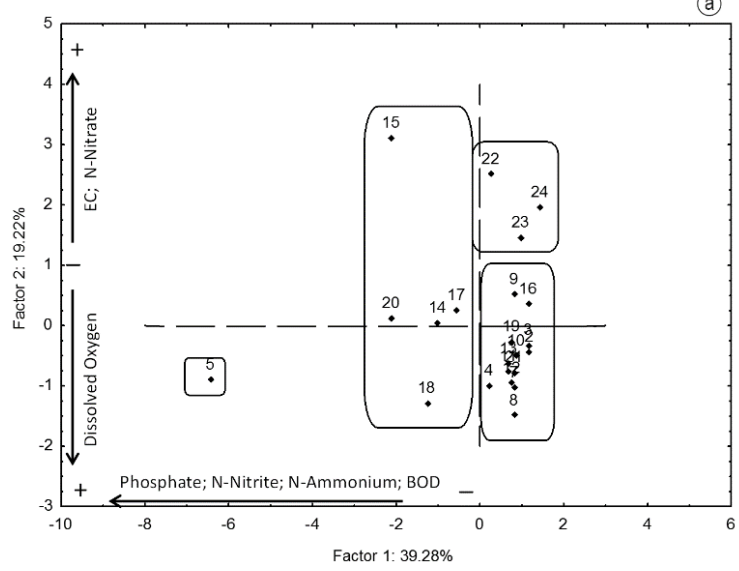

(b)

\begin{tabular}{ccc}
\hline Variablcs & Factor 1 Factor 2 \\
\hline EC $\left(\mathrm{mS} \mathrm{cm}^{-1}\right)$ & 0.18 & $\mathbf{0 . 6 7}$ \\
Phosphate $\left(\mathrm{mg} \mathrm{L}^{-1}\right)$ & $\mathbf{- 0 . 7 6}$ & 0.09 \\
N-Nitrate $\left(\mathrm{mg} \mathrm{L}^{-1}\right)$ & -0.31 & $\mathbf{0 . 8 1}$ \\
N-Nitrite $\left(\mathrm{mg} \mathrm{L}^{-1}\right)$ & $\mathbf{- 0 . 9 0}$ & 0.07 \\
N-Amm. $\left(\mathrm{mg} \mathrm{L}^{-1}\right)$ & $\mathbf{- 0 . 9 0}$ & 0.08 \\
DO $\left(\mathrm{mg} \mathrm{L}^{-1}\right)$ & $\mathbf{- 0 . 3 4}$ & $\mathbf{- 0 . 6 0}$ \\
BOD $\left(\mathrm{mg} \mathrm{L}^{-1}\right)$ & $\mathbf{- 0 . 8 2}$ & -0.12 \\
Ther.Col. (NMP) & 0.14 & 0.22 \\
\hline \% Explication & 39.28 & 19.22 \\
\hline
\end{tabular}

Figure 4. Principal Components Analysis of the sampling points of the Apodi/Mossoró river hydrographic basin, in the month of November of 2007. a) Representation of the two first PCA components; b) Variables correlation values. EC: Electric Conductivity; N-Amm.: Ammoniacal nitrogen; DO: Dissolved oxygen; BOD: Biochemical Oxygen Demand; Ther. Col.: Thermotolerant Coliforms.

(a)

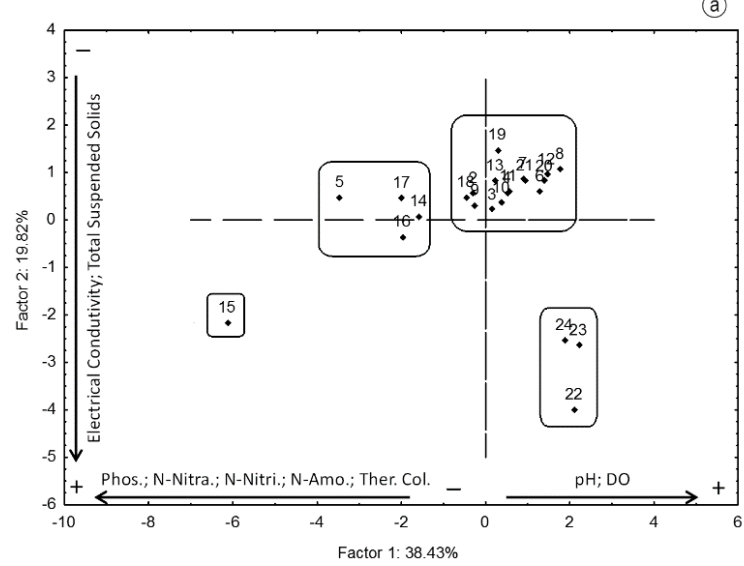

(b)

\begin{tabular}{ccc}
\hline Variables & \multicolumn{2}{c}{ Factor 1 Factor 2 } \\
\hline EC $\left(\mathrm{mS} \mathrm{cm}^{-1}\right)$ & 0.40 & $\mathbf{- 0 . 8 8}$ \\
TDS $\left(\mathrm{mg} \mathrm{L}^{-1}\right)$ & 0.40 & $\mathbf{- 0 . 8 8}$ \\
$\mathrm{pH}$ & $\mathbf{0 . 5 9}$ & 0.15 \\
Phosphate $\left(\mathrm{mg} \mathrm{L}^{-1}\right)$ & $\mathbf{- 0 . 7 4}$ & -0.15 \\
N-Nitrate $\left(\mathrm{mg} \mathrm{L}^{-1}\right)$ & $\mathbf{- 0 . 6 8}$ & -0.44 \\
N-Nitrite $\left(\mathrm{mg} \mathrm{L}^{-1}\right)$ & $\mathbf{- 0 . 7 2}$ & -0.22 \\
N-Amm. $\left(\mathrm{mg} \mathrm{L}^{-1}\right)$ & $\mathbf{- 0 . 6 1}$ & 0.03 \\
DO $\left(\mathrm{mg} \mathrm{L}^{-1}\right)$ & $\mathbf{0 . 6 6}$ & 0.20 \\
BOD (mg L $)$ & -0.45 & 0.30 \\
Ther.Col. (NMP) & $\mathbf{- 0 . 8 1}$ & -0.09 \\
\hline \% Explication & 38.43 & 19.82 \\
\hline
\end{tabular}

Figure 5. Principal Components Analysis of the sampling points of the Apodi/Mossoró river hydrographic basin, in the month of February of 2008. a) Representation of the two first PCA components; b) Variables correlation values. EC: Electric Conductivity; TDS: Total dissolved solids; N-Amm.: Ammoniacal nitrogen; DO: Dissolved oxygen; BOD: Biochemical Oxygen Demand; Ther. Col.: Thermotolerant Coliforms. 


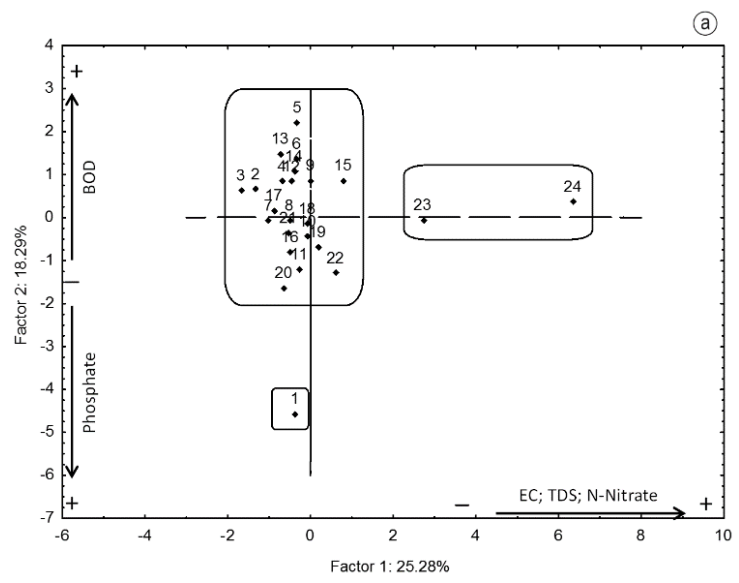

\begin{tabular}{|c|c|c|}
\hline Variables & \multicolumn{2}{|c|}{ Factor 1 Factor 2} \\
\hline $\mathrm{EC}\left(\mathrm{mS} \mathrm{cm}^{-1}\right)$ & 0.91 & 0.01 \\
\hline TDS (mg L $\left.{ }^{-1}\right)$ & 0.92 & 0.00 \\
\hline $\mathrm{pH}$ & 0.26 & -0.05 \\
\hline Phosphate (mg L ${ }^{-1}$ ) & -0.05 & -0.72 \\
\hline N-Nitrate (mg L ${ }^{-1}$ ) & 0.88 & 0.03 \\
\hline N-Nitrite (mg L ${ }^{-1}$ ) & 0.08 & 0.28 \\
\hline N-Amm. $\left(\mathrm{mg} \mathrm{L}^{-1}\right)$ & 0.11 & -0.52 \\
\hline $\mathrm{DO}\left(\mathrm{mg} \mathrm{L}^{-1}\right)$ & -0.02 & -0.56 \\
\hline $\mathrm{BOD}\left(\mathrm{mg} \mathrm{L}^{-1}\right)$ & -0.06 & 0.72 \\
\hline Ther.Col. (NMP) & 0.03 & 0.36 \\
\hline$\%$ Explication & 25.28 & 18.29 \\
\hline
\end{tabular}

Figure 6. Principal Components Analysis of the sampling points of the Apodi/Mossoró river hydrographic basin, in the month of May of 2008. a) Representation of the two first PCA components; b) Variables correlation values. EC: Electric Conductivity; TDS: Total dissolved solids; N-Amm.: Ammoniacal nitrogen; DO: Dissolved oxygen; BOD: Biochemical Oxygen Demand; Ther. Col.: Thermotolerant Coliforms.
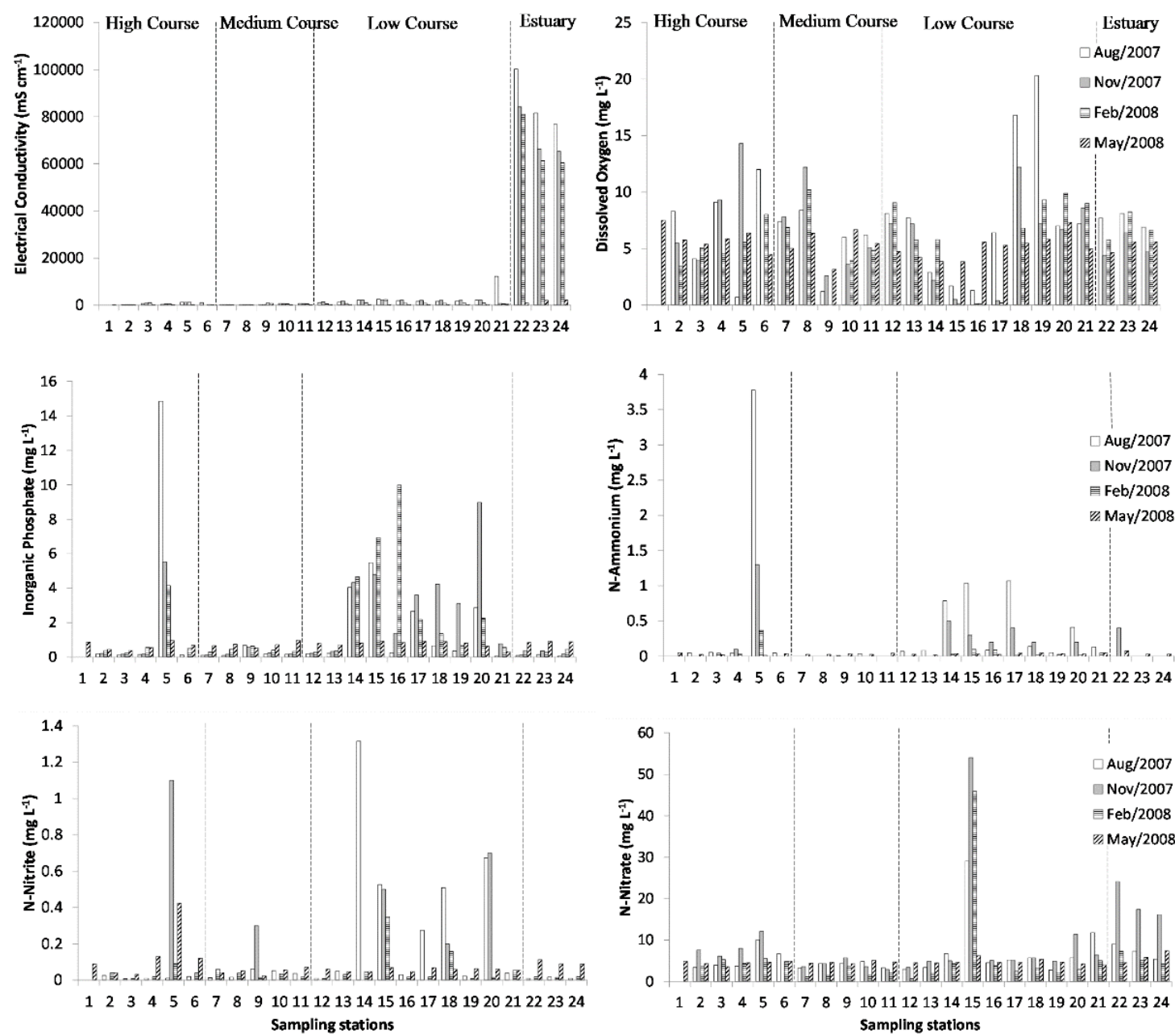

Figure 7. Values of some water quality parameters analyzed for the aquatic ecosystems of the Apodi/Mossoró river hydrographic basin, throughout the four collections. 
reduced values of dissolved oxygen found in these sampling stations.

The sampling station five (urban area of the Pau dos Ferros) was the most affected by anthropic activities, especially noticed by the high values of nutrients, in special the $\mathrm{N}$-ammonium $\left(3.7 \mathrm{mg} \mathrm{L}^{-1}\right.$ in August 2007). This point presented also high values of $\mathrm{BOD}$ (37.91 $\mathrm{mg} \mathrm{L}^{-1}$ ), indicating the contribution of a great amount of organic compounds, where the bacteria and other microorganisms act in the decomposition process, and consequently causing the consumption of dissolved oxygen and raising the water nutrient content.

High values of phosphate had been found in the high and low parts of the hydrographic basin in stretches that cross urban zones, such as the ones in Pau dos Ferros and Mossoró cities, when compared with other papers that had evaluated the nutrients concentrations along watersheds submitted to anthropic interferences. Henry-Silva \& Camargo (2000) had found total phosphorus (P-total) concentration of $1.2 \mathrm{mg} \mathrm{L}^{-1}$ in Ribeirão Claro (SP), located in the basin of the Corumbataí river (SP), whereas Ternus et al. (2011) when evaluating lotic environments of the high point of the Uruguay river basin (SC) that cross urban and rural areas found maximum value of $0.58 \mathrm{mg} \mathrm{L}^{-1}$ for P-total. Sant'Anna et al. (2007), when verifying the effect of the sewers discharges in streams of the estuary region of the Itanhaém river (SP) had found maximum value of P-total of $1.3 \mathrm{mg} \mathrm{L}^{-1}$. In general, the spatial pattern in watersheds, either in temperate and tropical zones, suggest that in areas disturbed by human activity the concentrations of most ions and inorganic nutrients are higher than the undisturbed areas (Silva et al., 2012). The present study corroborates this pattern.

In stations within urban areas were also found high concentrations of nitrogen compounds, which may compromise human activities like fishing performed throughout these regions, since the noionized ammonia in high concentrations can harm the transformation of the energy of foods in ATP, inhibiting the growth of the fish. The toxicity of ammonia for freshwater fish can vary due to the characteristics of the species, developmental stage, duration of the exposition and environmental conditions. Person-Le Ruyet et al. (1995) had found that the average lethal concentration (50 LC - 96 h) of $\mathrm{N}$-ammonium for teleostean freshwater fishes was of $0.82 \mathrm{mg} \mathrm{L}^{-1}$. In general, toxic no-ionized ammonia levels for Nile tilapia (Oreochromis niloticus) are between 0.6 and $2.0 \mathrm{mg} \mathrm{L}^{-1}$, during short period of exposition (El-Shafai et al., 2004). Besides high values of $\mathrm{N}$-ammonium, the point five and the points within the city of Mossoró presented dissolved oxygen levels as low as $0.7 \mathrm{mg}$ $\mathrm{L}^{-1}$ (Figure 7), what represents a critical level for aquatic biota in general.

Values of dissolved oxygen lower than $2.0 \mathrm{mg}$ $\mathrm{L}^{-1}$ can compromise the survival of the majority of the aquatic communities, especially when continuously exposed to these low concentrations (Felizardo et al., 2010). The smaller values of dissolved oxygen were observed next to the urban centers, which launch domestic sewers without treatment into the river. The general pattern is that the reduced levels of dissolved oxygen of aquatic environments are consequences of anthropic interferences (Neal et al., 2006), corroborating the pattern found in the Apodi/Mossoró river hydrographic basin. The occasional raised values of dissolved oxygen found in stretches that cross the urban area of Mossoró (low part of the basin) had been related with the photosyntheses performed by the phytoplankton in that moment. The high productivity of an aquatic system tends to result in high concentrations of oxygen during the day, exactly due to photosynthesis activity.

A specific set of sampling points were identified in the lowest course of the watershed, in the proximity of the estuary zone. These stations (22, 23 and 24) were characterized by high electric conductivity and total dissolved solids and these characteristics probably are related with the great amount of ions dissolved in the water of this region. In addition, it must be considered that in water bodies located in regions of sea influence it is natural to happen a great increase in the electric condutivity, once the concentration of ions raises itself due to the contribution of seawater. In fact, Jarvie et al. (2001) while studying lentic environments and the coastal influence, verified that streams that received salt contributions from salt water showed superior values of electric conductivity in comparison to other streams.

The majority of the points located in the medium and high courses of the hydrographic basin, and which were not within urban areas, had presented low values of nutrients, electric condutivity, thermotolerant coliforms, total dissolved solids, and presented relatively higher values of oxygen for all months considered.

In the month of May 2008 there was running water in point one, high course of the Apodi/ Mossoró river hydrographic basin. In this station 
was found the smallest value of BOD $\left(0.57 \mathrm{mg} \mathrm{L}^{-1}\right)$ and absence of thermotolerants coliforms. In the rainy period was observed that 21 sampling points were within one single PCA group, gathering places situated in the high, medium and low courses of the watershed. Possibly the similarity between the majority of the sampling points had been related with the pluviometric regimen, once that in 2008 rains had concentrated from March to May, this fact may have been the main factor that caused a homogeneity of the limnological characteristics, independent of where in the basin were the points located and the anthropic impacts that they were submitted.

With the gotten results, it was not possible to establish a longitudinal gradient of physicochemical characteristics within the aquatic ecosystems of the Apodi/Mossoró river basin. The absence of this longitudinal gradation can be explained by the anthropic influences to which these environments are submitted, with prominence for the construction of reservoirs and the discharges of domestic effluent by the cities of Pau dos Ferros and Mossoró. Since the intense rains that had occurred at the beginning of 2008 had been important for the homogenization of the physical, chemical and microbiological caractheristics of aquatic environments of the hydrographic basin. The majority of these interferences causes disturbances that take these environments to a non-natural state, where the predictions proposals for theoretical models of great application as the RCC and other models based on longitudinal patterns are not valid.

One of the main problems in the indiscriminate application of the River Continuum is the difficulty to find natural aquatic ecosystems that have not suffered anthropic interferences (Janauer, 2000). Beyond anthropic alterations, in aquatic environments of the semiarid, where the periods of drought and rain are well defined, a pattern of physical, chemical and biological alterations from the headwater to the estuary region hardly will be found, either for the intermittency of aquatic ambiences in the period of drought, either for rains that tend to provide the homogenization of the limnological characteristics of these environments, impeding the existence of a longitudinal pattern.

The results found in this study had indicated the absence of a longitudinal gradient as proposed in RCC. Araújo et al. (2009), studying a river in the Brazilian Southeast, had attributed the no validation of the RCC to the geography of the hydrographic basin in matter, where the presence of meadows had not offered the inherent conditions of ciliary covering to the River Continuum. Wei et al. (2009), studying the impact of a dam in China, pointed out that the organic pollution affects the physicochemical and biological processes of the system, and the construction of dams cause negative impacts downstream and upstream, with the decrease of the quality of water and the capacity of auto depuration of these environments. Bowes et al. (2003), when evaluating the concentrations of phosphate in a longitudinal gradient of the Swale river in England, had found the lack of a river continuum because the contribution of the phosphate that derives from urban effluents and rural activities. Other studies had also observed that the functioning of lotic ecosystems only fit themselves partially in the predictions proposed by the RCC (Heino et al., 2005; Paller et al., 2006; Houghton, 2007; Gustafson, 2008).

In the Apodi/Mossoró river hydrographic basin, the physical, chemical and microbiological characteristics of aquatic ecosystems are influenced predominantly by the pluviometric regimen, since the longitudinal continuum of these properties seems not to be the main model to understand the functioning of these ecosystems. Picard \& Lair (2005), when studying the plankton community of a river in France, also had not observed the occurrence of the predictions made by the RCC, attributing this fact to the local hydromorfological conditions, and also point out that the Flood Pulse performs the main influence in the structure and dynamics of the communities. In fact, Thomaz et al. (2007) state that the homogenization of habitats in lotic aquatic ecosystems after the flood pulse is a general pattern.

In the aquatic environments of the Apodi/ Mossoró river hydrographic basin the intense rains in certain years have a crucial role in the determination of the water characteristics, may causing unexpected flood pulses with unimodal characteristics that tend to homogenize the limnological properties of aquatic environments. Thus, it is evidenced that the dynamics between the periods of rain and drought is a mechanism that exerts a well defined regulation on aquatic ecosystems of the hydrographic basin in study, and probably ecological concepts that consider such dynamics are more applicable to these environments.

\section{Conclusions}

Due to anthropogenic interference that the watershed is submitted, it was not possible to detect a gradient of physical, chemical and microbiological 
characteristics along the Apodi/Mossoró river basin, probably because the anthropogenic interference which tends to eliminate a possible longitudinal gradient, acting as disturbances in aquatic ecosystems. We found that the sources of pollution, particularly the release of domestic sewage are the main pressures to the aquatic ecosystems studied. The rainfall and drought patterns acted directly on the physical, chemical and microbiological characteristics of the aquatic ecosystems. During the dry period, the values of nutrients and thermotolerant coliforms increased. In the rainy season occurred homogenization of the limnological variables, with reduced values of nutrients and biochemical oxygen demand, probably due to dilution caused by rainwater.

\section{References}

ARAÚJO, F.G., PINTO, B.C.T. and TEIXEIRA, T.P. Longitudinal patterns of fish assemblages in a large tropical river in southeastern Brazil: evaluating environmental influences and some concepts in river ecology. Hydrobiologia, 2009, 618(1), 89-107. http:// dx.doi.org/10.1007/s10750-008-9551-5.

BOUROCHE, J.M. and SAPORTA, G. Análise de dados. Rio de Janeiro: Zahar, 1982, $116 \mathrm{p}$.

BOWES, M.J., HOUSE, W.A. and HODGKINSON, R.A. Phosphorus dynamics along a river continuum. The Science of the Total Environment, 2003, 313(13), 199-212. http://dx.doi.org/10.1016/S00489697(03)00260-2. PMid:12922071

EL-SHAFAI, S.A., EL-GOHARY, F.A., NASR, F.A., VAN DER STEEN, N.P. and GIJZEN, H.J. Chronic ammonia toxicity to duckweed-fed tilapia (Oreochromis niloticus). Aquaculture (Amsterdam, Netherlands), 2004, 232(1-4), 117-127. http:// dx.doi.org/10.1016/S0044-8486(03)00516-7.

ELWOOD, J.W., NEWBOLD, J.D., O’NEILL, R.V. and VAN WINKKLE, V. Resource spiralling an operational paradigm for analysing lotic ecosystem. In T.D. FONTAINE and S.M. BARTHEL, eds. Dynamic of lotic ecosystems. Michigan: Ann Arbor Science, 1983, pp. 3-27.

FELIZARDO, V.O., MELLO, R.A., ANDRADE, E.S., PAULA, D.A.J., PAULINO, M.S. and MURGAS, L.D.S. Níveis de oxigênio em modelo reduzido para mandi amarelo (Pimelodus maculatus) na Usina Hidrelétrica do Funil. Boletim Instituto de Pesca, 2010, 36(3), 197-204.

GOLTERMAN, H.L., CLIMO, R.S. and OHNSTAD, M.A.M. Methods for physical and chemical analysis of fresh waters. 2nd ed. Oxford: IBP, 1978, 213 p.

GUSTAFSON, M.P. Effects of thermal regime on mayfly assemblages in mountain streams. Hydrobiologia,
2008, 605(1), 235-246. http://dx.doi.org/10.1007/ s10750-008-9357-5.

HANSSON, L., FAHRIG, L. and MERRIAM, G., eds. Mosaic landscape and ecological processes. London: Chapman \& Hall, 1995, 380 p. http://dx.doi. org/10.1007/978-94-011-0717-4.

HEINO, J., PARVIAINEN, J., PAAVOLA, R., JEHLE, M., LOUHI, P. and MUOTKA, T. Characterizing macroinvertebrate assemblage structure in relation to stream size and tributary position. Hydrobiologia, 2005, 539(1), 121-130. http://dx.doi.org/10.1007/ s10750-004-3914-3.

HENRY-SILVA, G.G. and CAMARGO, A.F.M. Impacto do lançamento de efluentes urbanos sobre alguns ecossistemas aquáticos do município de Rio Claro (SP). Revista Ciências Biologicas e do Ambiente, 2000, 2, 317-330.

HOUGHTON, D.C. The effects of landscape-level disturbance on the composition of Minnesota caddisfly (Insecta: Trichoptera) trophic functional groups: evidence for ecosystem homogenization. Environmental Monitoring and Assessment, 2007, 135(1-3), 253-264. http://dx.doi.org/10.1007/ s10661-007-9647-9. PMid:17345008

JANAUER, G.A. Ecohydrology: fusing concepts and scales. Ecological Engineering, 2000, 16(1), 9-16. http://dx.doi.org/10.1016/S0925-8574(00)00072-0.

JARVIE, H.P., NEAL, C., SMART, R., OWEN, R., FRASER, D., FORBES, I. and WADE, A. Use of continuous water quality records for hydrograph separation and to assess short-term variability and extremes in acidity and dissolved carbon dioxide for the River Dee, Scotland. The Science of the Total Environment, 2001, 265(1-3), 85-98. http:// dx.doi.org/10.1016/S0048-9697(00)00651-3. PMid:11227285

JOHNSON, B.L., RICHARDSON, W.B. and NAIMO, T.J. Past, present and future concepts in large river ecology. Bioscience, 1995, 45(3), 134-141. http://dx.doi.org/10.2307/1312552.

KOROLEFF, F. Determination of nutrients. In K. GRASSHOFF, ed. Methods of seawater analysis. New York: Verlag Chemie Weinhein, 1976, pp. 117-181.

MACKERETH, F.J.H., HERON, J. and TALLING, J.F. Water analysis: some revised methods for limnologists. London: Freshwater Biological Association, 1978, $121 \mathrm{p}$.

NEAL, C., NEAL, M., HILL, L. and WICKHAM, H. The water quality of the River Thame in the Thames Basin of south/south-eastern England. The Science of the Total Environment, 2006, 360(1-3), 254-271. http://dx.doi.org/10.1016/j.scitotenv.2005.08.039. PMid:16253309

PALLER, M.H., SPECHT, W.L. and DYER, S.A. Effects of stream size on taxa richness and other commonly used benthic bioassessmentmetrics. Hydrobiologia, 
2006, 568(1), 309-316. http://dx.doi.org/10.1007/ s10750-006-0208-y.

PICARD, V. and LAIR, N. Spatio-temporal investigations on the planktonic organisms of the Middle Loire (France), during the low water period: biodiversity and community dynamics. Hydrobiologia, 2005, 551(1), 69-86. http://dx.doi.org/10.1007/s10750005-4451-4.

RUYET, J.P.-L., CHARTOIS, H. and QUEMENER, L. Comparative acute ammonia toxicity in marine fish and plasma ammonia response. Aquaculture (Amsterdam, Netherlands), 1995, 136(1-2), 181-194. http://dx.doi.org/10.1016/0044-8486(95)01026-2.

SANT'ANNA, E.B., CAMARGO, A F.M. and BONOCCHI, K.S.L. Effects of domestic sewage discharges in the estuarine region of the Itanhaém River basin (SP, Brazil). Acta Limnologica Brasiliensia, 2007, 19(2), 221-232.

SCHIAVETTI, A. and CAMARGO, A.F.M. Conceitos de bacias hidrográficas: teorias e aplicaçôes. Ilhéus: Editus/ Editora da UESC, 2002, 293 p.

SILVA, D.M.L., CAMARGO, P.B., MCDOWELL, W.H., VIEIRA, I., SALOMÃO, M.S. and MARTINELLI, L.A. Influence of land use changes on water chemistry in streams in the State of Sáo Paulo, southeast Brazil. Anais da Academia Brasileira de Ciencias, 2012, 84(4), 919-930. http:// dx.doi.org/10.1590/S0001-37652012000400007. PMid:23207700

SMITH, S.W. and PETRERE JUNIOR, M. Caracterizaçáo limnológica da bacia de drenagem do Rio Sorocaba, São Paulo, Brasil. Acta Limnologica Brasiliensia, 2001, 12, 173-186.

STATZNER, B. and HIGLER, B. Questions and comments on the river continuum concept. Canadian Journal of Fisheries and Aquatic Sciences, 1985, 42(5), 1038-1044. http://dx.doi.org/10.1139/f85-129.

TERNUS, R.Z., SOUZA-FRANCO, G.M., ANSELMINI, M.E.K., MOCELLIN, D.J.C. and DAL MAGRO, J. Influence of urbanisation on water quality in the basin of the upper Uruguay River in western Santa Catarina, Brazil. Acta Limnologica Brasiliensia, 2011, 23(2), 189-199. http://dx.doi. org/10.1590/S2179-975X2011000200009.

THOMAZ, S.M., BINI, L.M. and BOZELLI, R.L. Floods increase similarity among aquatic habitats in river-floodplain systems. Hydrobiologia, 2007, 579(1), 1-13. http://dx.doi.org/10.1007/s10750006-0285-y.

THORP, J.H., THOMS, M.C. and DELONG, M.D. The riverine ecosystem synthesis: biocomplexity in river networks across space and time. River Research and Applications, 2006, 22(2), 123-147. http:// dx.doi.org/10.1002/rra.901.

VANNOTE, R.L., MINSHALL, G.W., CUMMINS, K.W., SEDELL, J.R. and CUSHING, C.E. The river continuum concept. Canadian Journal of Fisheries and Aquatic Sciences, 1980, 37(1), 130-137. http:// dx.doi.org/10.1139/f80-017.

WARD, J.V. and STANFORD, J.A. The serial discontinuity concept in lotic ecosystems. In T.D. FONTAINE and S.M. BARTHEL, eds. Dynamic of lotic ecosystems. Michigan: Ann Arbor Science, 1983, pp. 347-356.

WEI, G., YANG, Z., CUI, B., LI, B., CHEN, H., BAI, J. and DONG, S. Impact of dam construction on water quality and water self-purification capacity of the Lancang River, China. Water Resources Management, 2009, 23(9), 1763-1780. http://dx.doi. org/10.1007/s11269-008-9351-8.

WU, Y., LIU, S. and GALLANT, A.L. Predicting impacts of increased $\mathrm{CO}_{2}$ and climate change on the water cycle and water quality in the semiarid James River Basin of the Midwestern USA. The Science of the Total Environment, 2012, 430, 150-160. http://dx.doi.org/10.1016/j.scitotenv.2012.04.058. PMid:22641243

Received: 30 April 2014 Accepted: 02 December 2014 